\title{
Raw Material Order Allocation Problem Using Mixed Integer Linear Programming and Simulation
}

\author{
Ary Tri Wibowo \\ Department of Industrial and Systems Engineering, \\ Institut Teknologi Sepuluh Nopember, Indonesia \\ Email: arywibowo2008@gmail.com \\ Niniet Indah Arvitrida \\ Department of Industrial and Systems Engineering, \\ Institut Teknologi Sepuluh Nopember, Indonesia \\ Email: niniet@ie.its.ac.id (Corresponding Author) \\ Erwin Widodo \\ Department of Industrial and Systems Engineering, \\ Institut Teknologi Sepuluh Nopember, Indonesia \\ Email: erwin@ie.its.ac.id
}

\begin{abstract}
This study aims to provide a conceptual model and to develop a mathematical model to determine order allocation in multi products, multi suppliers, multi carriers, and multi periods problem under uncertainty. The conceptual model describes the connection between related variables. The problem is formulated in mixed integer linear programming (MILP) model. MILP model objective function is to minimize supply chain costs which are purchasing cost, ordering cost, inventory holding cost, carrier cost, late delivery penalty cost, and low-quality penalty cost. In order to illustrate the applicability of the MILP model, a real-world case in cement industry is demonstrated. Based on historical data, the most common uncertainty factor is supplier delivery performance and product quality. Those factors are experimented in MILP model using Monte Carlo simulation. The integration between MILP model and Monte Carlo simulation shows that the proposed model resulted a global optimum solution.
\end{abstract}

Keywords: order allocation, optimization, simulation, supplier selection, linear programming

\section{INTRODUCTION}

The global industrial competition is getting more intense. Many players attempt to improve their business process in order to gain competitive advantage. They cooperate and coordinate amongst themselves to get more efficiency in their business operations. Higher efficiency helps a company achieve competitive advantage (Hosseini et al., 2018). Many factors in today's global market have forced companies to gain a competitive advantage by focusing attention to their entire supply chain (Mendoza \& Ventura, 2010). In a supply chain, sourcing is one of the most strategic aspect when a company attempts to reduce cost and improve competitiveness (Xia \& Wu, 2007). One of the crucial steps in sourcing is supplier selection process. Selecting the best suppliers and allocating orders to the selected suppliers is a significant business process (Jolai et al., 2011). Selecting the right suppliers is a key to the procurement process and represents a major opportunity for companies to reduce costs (Kumar et al., 2018). A proper supplier selection process gives an opportunity to cost reduction that affects the company efficiency.

The aspect that becomes an issue in selecting supplier selection is the method for selecting the best supplier. The supplier selection problem can be either a single-sourcing problem, in which one supplier is selected to satisfy the firm's entire demand, or a multiple-sourcing problem, in which more than one supplier is selected (Hamdan \& Cheaitou, 2017). Ustun \& Demirtas (2008) in their paper said basically there are two kinds of supplier selection problem. In the first kind of supplier selection, one supplier can satisfy all the buyer's needs (single sourcing). The management needs to make only one decision: which supplier is the best. In the second type (multiple sourcing), no supplier can satisfy all the buyer's requirements. The use of single sourcing if a supplier can meet all the needs of buyer such as quality, quantity, and delivery, while multiple sourcing if there is no single supplier that can meet all the needs of buyers due to various limitations such as capacity, price, quality level, and delivery time (Ware et al., 2014).

Many authors have published some research about multiple-sourcing selection. Those studies aimed to provide a procedure or a tool to select the best feasible alternative in decision making. Choudhary \& Shankar (2013) developed mixed integer linear programming (MILP) model considering purchasing cost, order cost, inventory holding cost, late delivered product cost, using multi carriers for multi suppliers in multi periods. Wicaksono et al. (2018) also provided a MILP model considering discounts using a single carrier for multi products, multi suppliers in multi periods. Another research by Wicaksono et al. (2019), the authors integrated carrier selection into a DSSP model where 
multiple products are procured from multiple suppliers (Wicaksono et al., 2019). Romero-Hernandez et al. (2021) proposed a modified Quality Function Deployment (QFD) approach to be an integrated framework for supply chain selection. This methodology is applied for a start up company to balance between fulfillment and availability of supply chain. A research conducted by Mujkic et al. (2018) shows that different supply chain mathematical models and formulations applied in sustainability dimensions. The research also describes that most authors adopted MILP as the modelling approach. However, only few research considering uncertainty and randomness in their paper. According to Chen et al. (2006), the supplier selection may involve several and different criteria, a combination of different decision models, group decision-making and various forms of uncertainty.

In this paper, we provide a conceptual model to show the multi products, multi suppliers, multi carriers, and multi periods problem in a diagram. We also develop a mathematical model in mixed integer linear programming (MILP) model to determine the optimum order allocation solution. We experiment with the model by generating random value in delivery performance and product quality as the uncertainty factors. These two factors are most common uncertainty factor and also have a financial impact, like a penalty cost to a supplier who cannot meet the buyer requirement. We use Monte Carlo simulation to generate random value and combine the result to the MILP model. The Monte Carlo method of statistical analysis uses random time series generated with spectral characteristics similar to the actual data time series used in producing the statistic fields (Stanford \& Ziemke, 1994). Monte Carlo experimentation is the use of simulated random numbers to estimate some functions of a probability distribution (Gentle, 2010). Therefore, this study aims to provide a decisionmaking model to solve multi products, multi suppliers, multi carriers, and multi periods order allocation problem under uncertainty.

This paper is divided into 5 sections. Section 1 discusses about the background of this research. The next section presents a literature review and gap on previous research. Third section provides the development model, including conceptual model and MILP model. Section 4 shows data experiment in the real-world case. Finally, the last section discusses about conclusion and future research.

\section{LITERATURE REVIEW}

In supply chain management, supplier selection is a part of purchasing process. The stage of supplier selection starts from identifying, evaluating and selecting the best supplier in accordance with particular criteria. The purchasing function is increasingly seen as a strategic issue in organizations. Buyer and supplier relationships in manufacturing enterprises have received a great deal of attention (Chen, Lin \& Huang, 2006). In traditional practices, first suppliers are selected, and then the buyer, by taking some other considerations and side constraints into account, makes the final decision on how much to order from each. But in the recent decade, researchers have concentrated on integrated approaches in which the issues of supplier selection and order allocation are simultaneously investigated (Jolai et al., 2011).
Most of supplier selection and order allocation problem are multi objective issue. It means there is over one objective but conflicting each other. Pan \& Wang (2014) presented a multi-objective model of order allocation using mixed integer linear programming. Mendoza \& Ventura (2010) investigated supplier selection and order quantity allocation problem using non-linear programming and Power of Two (POT). The previous research mostly discussed quantitative aspect. Kumar et al. (2018) added qualitative aspect in their research. They developed supplier selection and order allocation model using Analytical Hierarchy Process (AHP) and Linear Physical Programming. Hamdan \& Cheatiou (2017) added green criteria on their approach. Using fuzzy TOPSIS, AHP, optimization, they proposed the model to solve supplier selection and order allocation problem. Wicaksono et al. (2018) developed a mixed integer linear programming (MILP) model considering discount in multi products, multi suppliers and multi periods. Choudhary \& Shankar (2013) developed MILP model to minimize purchasing cost, order cost, inventory holding cost, late delivered product cost using multi carriers for multi suppliers in multi periods but in a single product.

A list of literature review is depicted in Table 1. Many of these previous research already offered a multi-objective problems solution. The authors developed a model, but in limited variables. In this paper, we fulfill the drawback by examining all related variables into a single mathematical model. Only few literatures considered uncertainty and randomness into their model. Some of them are Hamdan \& Cheatiou (2017), Jolai et al., (2011), and Chen et al. (2006). The rest of the literature assume that all of the variables are constant and deterministic. We integrated the model with Monte Carlo simulation to accommodate uncertainty. Data experiment in real-world case is also applied to test the model. This study clearly aims to fulfill the gap in previous papers.

This research as mentioned above at least has three main contributions. The proposed model is consisted of more related variables. It makes the model more complex and closer to the real problem. The second one, integration Monte Carlo simulation into MILP model. This integration makes better approach than the previous research. The last contribution is about data experiment in real-world case. It is applied to test the feasibility of the proposed model.

\section{PROPOSED MODEL}

In this section, we provide a conceptual model and develop a mathematical model formulation. The conceptual model shows the relation between variable of products, suppliers, carrier, and periods. Mathematical model formulation shows indices, parameters, objective function, and decision variables of the order allocation problem. The problem for proposed model can be briefly described as follows: amount of multi products orders supplied by multi suppliers using multi carriers in multi periods. The objective function of this model is to minimize supply chain costs which are purchasing cost, order cost, inventory holding cost, carrier cost, late delivery penalty cost, and low-quality penalty cost. 


\begin{tabular}{|c|c|c|c|c|c|c|c|c|c|c|c|c|c|c|c|c|c|c|}
\hline \multirow[b]{2}{*}{ No } & \multirow[b]{2}{*}{ Title (Year) } & \multirow[b]{2}{*}{ Tool } & \multicolumn{16}{|c|}{ Variables } \\
\hline & & & 范 & 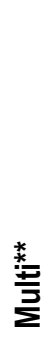 & $\begin{array}{l}\text { 䓂 } \\
\text { ơ } \\
\text { 号 }\end{array}$ & 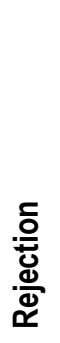 & 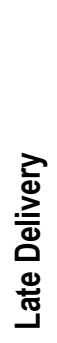 & 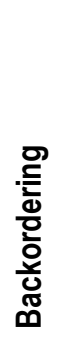 & 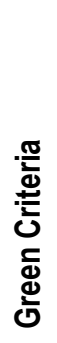 & 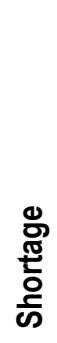 & $\begin{array}{l}\overleftarrow{\Delta} \\
\frac{0}{0} \\
\dot{0}\end{array}$ & 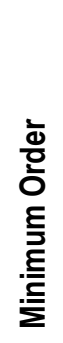 & 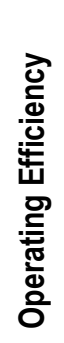 & 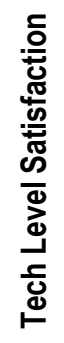 & 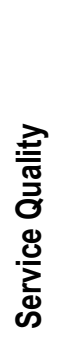 & 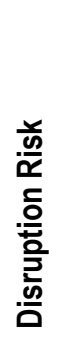 & $\frac{\text { 을 }}{\frac{\hbar}{\bar{t}}}$ & 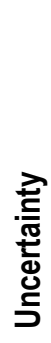 \\
\hline 1 & $\begin{array}{l}\text { Mixed integer linear programming model for dynamic } \\
\text { supplier selection problem considering discounts } \\
\text { (2018) }\end{array}$ & MILP & $F$ & $\mathrm{H}$ & $F$ & $F$ & $F$ & - & - & - & - & - & - & - & - & - & - & - \\
\hline 2 & $\begin{array}{l}\text { Joint decision of procurement lot-size, supplier } \\
\text { selection, and carrier selection (2013). }\end{array}$ & MILP & $F$ & $\mathrm{H}$ & $\mathrm{F}$ & $\mathrm{F}$ & $\mathrm{F}$ & - & - & - & - & - & - & - & - & - & - & - \\
\hline 3 & $\begin{array}{l}\text { Supplier selection and order allocation with green } \\
\text { criteria: An MCDM and multi-objective optimization } \\
\text { approach (2016). }\end{array}$ & $\begin{array}{l}\text { Fuzzy Topsis, AHP, Bi } \\
\text { Objective Integer \& } \\
\text { Non-Integer } \\
\text { Programming }\end{array}$ & $F$ & $\mathrm{H}$ & - & - & - & - & - & $\mathrm{F}$ & $\mathrm{F}$ & - & - & - & - & - & - & $\mathrm{F}$ \\
\hline 4 & $\begin{array}{l}\text { Integrating fuzzy TOPSIS and multi-period goal } \\
\text { programming for purchasing multiple products from } \\
\text { multiple suppliers (2011). }\end{array}$ & $\begin{array}{l}\text { Fuzzy Topsis, Fuzzy } \\
\text { AHP, Goal } \\
\text { Programming }\end{array}$ & $\mathrm{F}$ & $\mathrm{H}$ & - & $\mathrm{F}$ & - & - & - & - & $F$ & $\mathrm{~F}$ & - & - & - & - & - & $\mathrm{F}$ \\
\hline 5 & $\begin{array}{l}\text { Supplier Selection and Order Allocation in Supply } \\
\text { Chain (2018). }\end{array}$ & $\begin{array}{l}\text { AHP, Linear Physical } \\
\text { Programming }\end{array}$ & - & - & - & - & - & - & - & - & - & - & $\mathrm{F}$ & $\mathrm{F}$ & $F$ & - & - & - \\
\hline 6 & $\begin{array}{l}\text { A serial inventory system with supplier selection and } \\
\text { order quantity allocation (2010). }\end{array}$ & $\begin{array}{c}\text { Non-Linear } \\
\text { Programming, POT }\end{array}$ & $F$ & $\mathrm{H}$ & - & $F$ & - & - & - & - & - & - & - & - & - & - & - & - \\
\hline 7 & $\begin{array}{l}\text { Lot sizing and supplier selection with multiple items, } \\
\text { multiple periods, quantity discounts, and } \\
\text { backordering (2018). }\end{array}$ & MIP, Heuristics & $F$ & $\mathrm{H}$ & $\mathrm{F}$ & - & - & $F$ & - & $\mathrm{F}$ & - & - & - & - & - & - & - & - \\
\hline 8 & $\begin{array}{l}\text { A Multi-objective Model of Order Allocation under } \\
\text { Considering Disruption Risk and Scenario Analysis } \\
\text { in a Supply Chain Environment an Integrated Multi- } \\
\text { objective Model for Order Allocation (2014). }\end{array}$ & Multi Objective MILP & $\mathrm{F}$ & $\mathrm{H}$ & - & $\mathrm{F}$ & - & - & - & - & - & - & - & - & - & $\mathrm{F}$ & - & - \\
\hline
\end{tabular}


Table 1 Gap research (con't)

\begin{tabular}{|c|c|c|c|c|c|c|c|c|c|c|c|c|c|c|c|c|c|c|}
\hline \multirow[b]{2}{*}{ No } & \multirow[b]{2}{*}{ Title (Year) } & \multirow[b]{2}{*}{ Tool } & \multicolumn{16}{|c|}{ Variables } \\
\hline & & & 范 & $\frac{*}{F^{*}}$ & 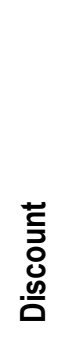 & 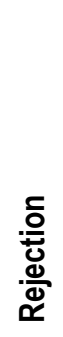 & 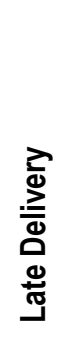 & 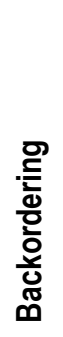 & 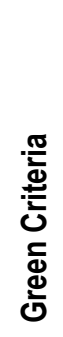 & 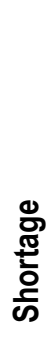 & 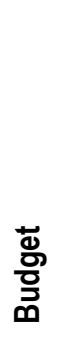 & 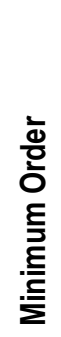 & 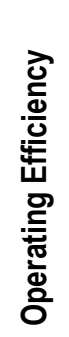 & 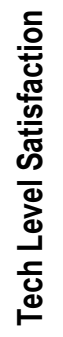 & 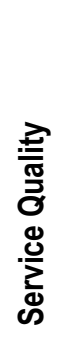 & 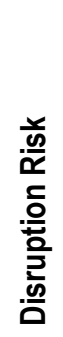 & 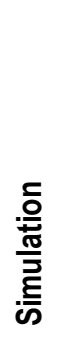 & .: \\
\hline 9 & $\begin{array}{l}\text { A fuzzy approach for supplier evaluation and } \\
\text { selection in supply chain management (2006) }\end{array}$ & Fuzzy Topsis & - & $\mathrm{H}$ & - & - & - & - & - & - & - & - & - & - & - & - & - & $\mathrm{F}$ \\
\hline 10 & $\begin{array}{l}\text { A mixed integer linear programming model for } \\
\text { dynamic supplier and carrier selection problems } \\
\text { (2019). }\end{array}$ & MILP & $F$ & $\mathrm{H}$ & $\mathrm{F}$ & $F$ & $\mathrm{~F}$ & - & - & - & - & - & - & - & - & - & - & - \\
\hline 11 & $\begin{array}{l}\text { Supplier selection with multiple criteria in volume } \\
\text { discount environments (2007). }\end{array}$ & $\begin{array}{l}\text { AHP, Mixed Integer } \\
\text { Programming }\end{array}$ & $\mathrm{H}$ & - & $\mathrm{F}$ & $F$ & $F$ & - & - & - & - & - & - & - & - & - & - & - \\
\hline 12 & $\begin{array}{l}\text { An integrated multi-objective decision-making } \\
\text { process for multi-period lot-sizing with supplier } \\
\text { selection (2008). }\end{array}$ & $\begin{array}{l}\text { ANP, Multi Objective } \\
\text { MILP }\end{array}$ & $\mathrm{F}$ & $\mathrm{H}$ & - & $F$ & - & - & - & - & - & - & - & - & - & - & - & - \\
\hline 13 & $\begin{array}{l}\text { A mixed-integer non-linear program to model } \\
\text { dynamic supplier selection problem (2014). }\end{array}$ & $\begin{array}{l}\text { Mixed Integer Non- } \\
\text { Linear Programming }\end{array}$ & $\mathrm{H}$ & $\mathrm{H}$ & - & $F$ & $\mathrm{~F}$ & - & - & - & - & - & - & - & - & - & - & - \\
\hline 14 & $\begin{array}{l}\text { A Heuristic Approach for Determining Lot Sized and } \\
\text { Schedules Using Power-of-Two Policy (2007) }\end{array}$ & POT & $\mathrm{H}$ & $\mathrm{H}$ & - & - & - & - & - & - & - & - & - & - & - & - & - & - \\
\hline 15 & This paper research (2020) & $\begin{array}{l}\text { MILP, Monte Carlo } \\
\text { simulation }\end{array}$ & $\mathrm{F}$ & $\mathrm{F}$ & - & $\mathrm{F}$ & $\mathrm{F}$ & - & - & - & - & - & - & - & - & - & $\mathrm{F}$ & $\mathrm{F}$ \\
\hline & & & & & & & & & & & & & & & hold & & & $\begin{array}{l}\text { Note: } \\
\text { cost. } \\
\text { iods. } \\
\text { ilable }\end{array}$ \\
\hline
\end{tabular}




\subsection{Conceptual Model}

A conceptual model is a diagram that shows the connection between variables. The model represents the real problem as a system. In this paper, the variables are suppliers, carrier modes, raw materials as treated as products, and periods. Figure 1 shows the conceptual model.

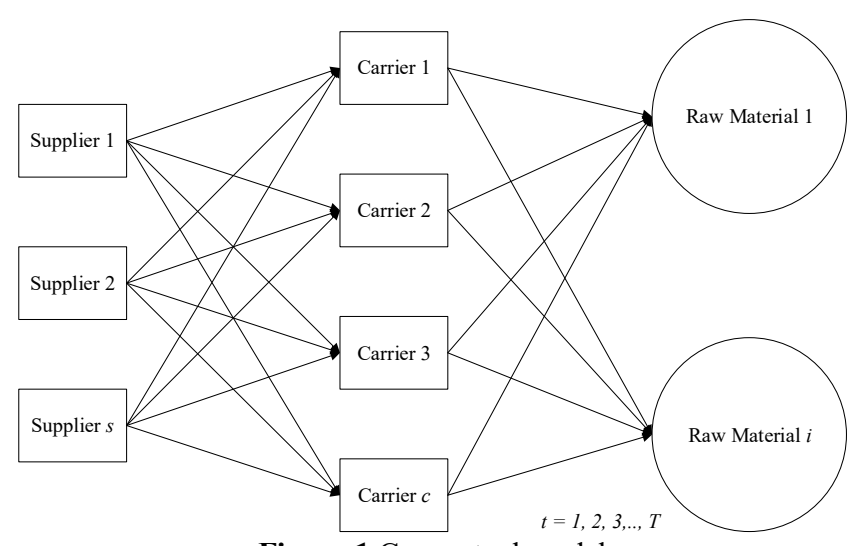

Figure 1 Conceptual model

The direction of the arrow to the right shows that the flow of material from the origin point (supply side) to fulfill the destination point (demand side). Each arrow brings some values. The value is the amount of order that must be delivered to fulfill the raw material demands and to satisfy the constraints. Variables also have some limitation called constraint. Variable of supplier has a supplier capacity constraint, variable of carrier has a carrier capacity constraint, and variable of raw material has a storage capacity constraint. The conceptual model describes how the demand of raw material $i$ is fulfilled by supplier $s$ that it used carrier $\mathrm{c}$ in period $\mathrm{t}$.

\subsection{Model Assumption}

These models are restricted by some assumptions. Demands are known and constant. The rest of order due to late delivery are allowed to be delivered in the next period. Product with low quality is accepted and stored at the buyer storage, but penalty cost is still charged. Shortages are not allowed. Carrier costs apply to supplier, not buyer. Carrier costs are charged at the full truckload (FTL) capacity tariff despite the amount which is carried less than FTL capacity. Lead time is constant. In this model, raw materials and products are substitutes.

\subsection{Model Indices, Parameters, and Decision Variables}

These followings are model indices, parameters, and decision variables for mathematical formulation in the next sub section.

Indices

$$
\begin{array}{ll}
i & \text { raw material; } 1,2, \ldots, I \\
s & \text { supplier; } 1,2, \ldots, S
\end{array}
$$

$\begin{array}{ll}c & \text { carrier; } 1,2, \ldots, C \\ t & \text { period; } 1,2, \ldots, T\end{array}$

Parameters

$\boldsymbol{U} \boldsymbol{C}_{\boldsymbol{i s}} \quad$ unit price of raw material $i$ supplied by supplier $S$

$\boldsymbol{D}_{i t}$ demand of raw material $i$ in period $t$

$\boldsymbol{O}_{\text {ist }} \quad$ order cost of raw material $i$ for supplier $s$ in period $t$

$\boldsymbol{B}_{\text {isct }} \quad$ carrier cost $c$ is used by supplier $s$ to supply raw material $i$ in period $t$

$\boldsymbol{L}_{\text {ist }} \quad$ raw material $i$ late delivery rate supplied by $s$ in period $t$

$\boldsymbol{P l}_{\text {ist }} \quad$ raw material $i$ late delivery penalty cost supplied by supplier $s$ in period $t$

$\boldsymbol{Q}_{\text {ist }} \quad$ raw material $i$ low quality rate supplied by supplier $s$ in period $t$

$\boldsymbol{P} \boldsymbol{q}_{\text {ist }} \quad$ raw material $i$ low quality penalty cost $i$ supplied by supplier $s$ in period $t$

$\boldsymbol{H C}_{\boldsymbol{i t}} \quad$ holding cost of raw material $i$ in period $t$

$\boldsymbol{I}_{\boldsymbol{i}} \quad$ inventory level of raw material $i$ in initial period $(t=0)$

$\boldsymbol{C C}_{\text {isct }} \quad$ carrier $c$ capacity to supply raw material $i$ used by supplier $s$ in period $t$ $\boldsymbol{C S}_{\text {ist }} \quad$ supplier $s$ capacity $s$ to supply raw material $i$ in period $t$

$\boldsymbol{S C}_{\boldsymbol{i t}} \quad$ storage capacity of raw material $i$ in period $t$

$\boldsymbol{n}_{\text {ist }} \quad$ minimum order level of raw material $i$ supplied by supplier $s$ in period $t$ according to management policy

MO $_{\text {ist }} \quad$ minimum order level of raw material $i$ supplied by supplier $s$ in period $t$ according to supplier requirement M a big number

Decision Variables

$\begin{array}{ll}\boldsymbol{X}_{\boldsymbol{i s c t}} & \begin{array}{l}\text { amount of raw material } i \text { order supplied } \\ \text { by supplier } s \text { using carrier } c \text { in period } t \\ \text { number of carrier } c \text { used by supplier } s \\ \boldsymbol{N}_{\boldsymbol{i s c t}}\end{array} \\ \begin{array}{l}\text { to supply raw material } i \text { in period } t \\ \boldsymbol{N} \boldsymbol{V}_{\boldsymbol{i t}}\end{array} & \begin{array}{l}\text { inventory level of raw material } i \text { in } \\ \text { period } t \\ \text { binary variable. } 1 \text { if supplier } s \text { is } \\ \text { selected, } 0 \text { if otherwise }\end{array}\end{array}$

\subsection{Model Formulation}

According to model indices, parameters, and decision variables above, a mathematical formulation may be as stated as follows: 
Minimize $Z=Z_{1}+Z_{2}+Z_{3}+Z_{4}+Z_{5}+Z_{6}$

$Z_{1}=\sum_{i} \sum_{s} \sum_{c} \sum_{t} X_{i s c t} * U C_{i s}$

$Z_{2}=\sum_{i} \sum_{s} \sum_{t} O_{i s t} * V_{s t}$

$Z_{3}=\sum_{i} \sum_{t} I N V_{i t} * H C_{i t}$

$Z_{4}=\sum_{i} \sum_{s} \sum_{c} \sum_{t} N_{i s c t} * B_{\text {isct }}$

$Z_{5}=\sum_{i} \sum_{s} \sum_{c} \sum_{t} X_{i s c t} * L_{i s t} * P l_{i s t}$

$Z_{6}=\sum_{i} \sum_{s} \sum_{c} \sum_{t} X_{i s c t} * Q_{i s t} * P q_{i s t}$

Subject to

$\begin{array}{ll}\sum_{s} \sum_{c} X_{i s c t}+I A_{i t} \geq D_{i t} & \forall i=1, \ldots, I ; \forall t=1 \\ \sum_{S} \sum_{c} X_{i s c t}+I N V_{i(t-1)} \geq D_{i t} & \forall i=1, \ldots, I ; \forall t \neq 1\end{array}$

$\sum_{s} \sum_{c} X_{i s c t}-\sum_{s} \sum_{c} X_{i s c t} * L_{i s c t}+I A_{i}$

$\sum_{s} \sum_{c} X_{i s c t}-\sum_{s} \sum_{c} X_{i s c t} * L_{i s c t}+\sum_{s} \sum_{c} X_{i s c(t-1)} * L_{i s c(t-1)}+I N V_{i(t-1)}$
$=D_{i t}+I N V_{i t} \quad \forall i=1, \ldots, I ; \forall t \neq 1$

$X_{\text {isct }} \leq N_{\text {isct }} * C C_{\text {isct }}$ $\forall i=1, \ldots, I ; \forall s=1, \ldots, S ; \forall c=1, \ldots, C ; \forall t=1, \ldots, T$

$\sum_{c} X_{i s c t} \leq C S_{i s t} \quad \forall i=1, \ldots, I ; \forall s=1, \ldots, S ; \forall t=1, \ldots, T$

$\sum_{i} \sum_{c} X_{i s c t} \leq M * V_{s t} \quad \forall s=1, \ldots, I ; \forall t=1, \ldots, T$

$I N V_{i t} \leq S C_{i t} \quad \forall i=1, \ldots, I ; \forall t=1, \ldots, T$

$\sum_{c} X_{i s c t} \geq n_{i s t} * D_{i t} \quad \forall i=1, \ldots, I ; \forall s=1, \ldots, S ; \forall t=1, \ldots, T$

$\sum_{c} X_{i s c t} \geq M O_{i s t} \quad \forall i=1, \ldots, I ; \forall s=1, \ldots, S ; \forall t=1, \ldots, T$

$X_{\text {isct }}, N_{\text {isct }} \geq 0$ and integer

$$
\forall i=1, \ldots, I ; \forall s=1, \ldots, S ; \forall c=1, \ldots, C ; \forall t=1, \ldots, T
$$

$V_{s t} \in\{0,1\}$

$$
\forall s=1, \ldots, I ; \forall t=1, \ldots, T
$$


The objective function (1) is to minimize purchasing cost (1a), order cost (1b), inventory holding cost (1c), carrier cost (1d), late delivery penalty cost (1e), and low-quality penalty cost (1f). In this proposed model, there are several constraints. The demand fulfillment constraint $(2 \mathrm{a}$ and $2 \mathrm{~b})$ is to ensure demand each period is fulfilled. Inventory balance constraint (3a and $3 \mathrm{~b}$ ) states balance of inventory level in period $t$. This constraint also to ensure the demand in period $t$ is fulfilled by inventory level in period $t$ and the amount of late order in period $t-1$. Carrier capacity constraint (4) is to ensure the amount of order not exceed the capacity of carrier. This constraint also decides number of carriers needed. Supplier capacity constraint (5) states the amount of order is not to be allowed to exceed supply capacity of supplier. Ordering cost constraint (6) is to ensure order cost applied if the supplier is selected. Storage capacity constraint (7) is to ensure the amount of order not exceed buyer storage capacity. Management policy constraint (8) is to ensure every supplier receives minimum order according to management company policy. Supplier requirement constraint (9) is to ensure minimum order must be greater equal than supplier requirements. Constraint number 10 forces integer and non-negativity value. Finally, constraint number 11 is a binary variable constraint.

\section{EXPERIMENTAL DATA}

In section 4 , we discuss how the proposed model demonstrated through data experiment. Data from real-world case in a cement industry is collected. It aims for illustrating how the model gain the solution. In cement production, a cement company needs some types of raw materials. They are limestone, clay, iron sand, silica sand, trass, and gypsum. Limestone and clay are usually mined from the company quarry itself. In this selected cement company, the gypsum must be purchased from single dedicated supplier. The rest of raw materials which are iron sand, silica sand, and trass, must be purchased from specific different suppliers. These suppliers are multiple dedicated suppliers. It means, based on management company policy, a whole aggregate order must be split into all suppliers. The result of field observation, iron sand is supplied by supplier D and E, trass is fulfilled by supplier F, G, and $\mathrm{H}$, then silica sand is purchased from supplier M, N, and O. Figure 2 depicts which suppliers fulfill what raw materials.
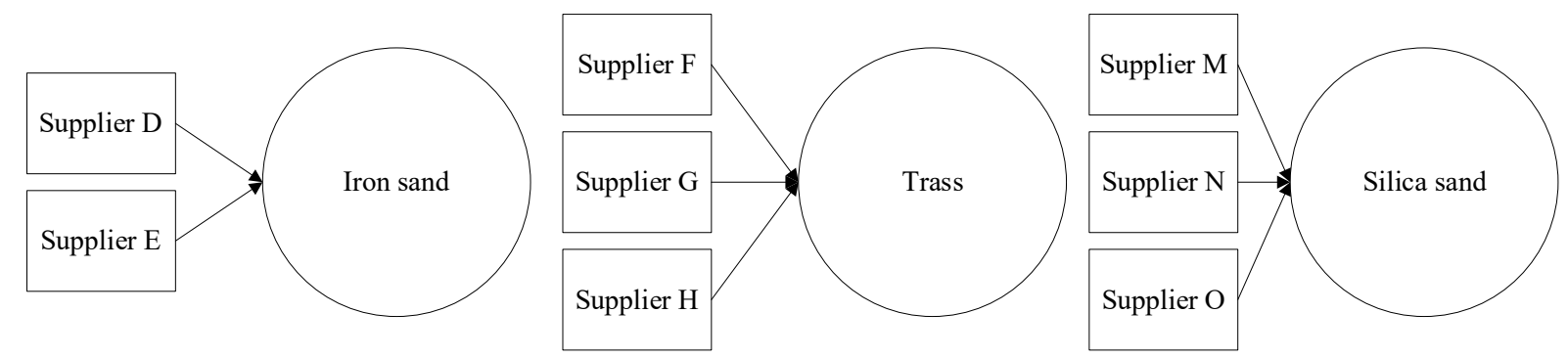

Figure 2 Raw material supplier

Data collection is started from unit price of raw materials to minimum order level as stated as in the previous section. We put the data into the parameter of the proposed model. All gathered data is assumed has no change along time horizon. A whole data parameter can be referred at Appendix.

We experiment parameter of raw material late delivery rate (List) and raw material low quality rate (Qist) as uncertainty factors before running the full mathematical model into optimization software called Lingo. Monte Carlo simulation is applied to imitate and to simulate the pattern of supplier delivery performance and product quality based on historical data. The result of the simulation effects on the amount of penalty cost suppliers must pay to the company. We divide the late delivery penalty cost into three events. It depends on the amount of supplier delivery that is sent on time according to the company order. The first event is no penalty applied, which means all the raw material completely delivered on time. The second event is if the supplier could only deliver $50 \%$ to $99 \%$ of raw materials ordered on the right time, they may be charged $2.5 \%$ penalty. Maximum penalty $5 \%$ is applied, if the suppliers send under $50 \%$ of raw materials ordered on schedule. We count the frequency of events according to the delivery performance from historical data. Then, we convert the frequency distributions to cumulative frequency/probability distributions. Put the interval of random numbers on each event. Tersine (1994) states sample at random from the cumulative probability distributions to determine specific variable values to use in the simulation. For instance, Table 2 shows the result of supplier D late delivery rate distribution.

Table 2 Supplier D late delivery rate distribution

\begin{tabular}{lccccc}
\hline $\begin{array}{c}\text { Penalty } \\
\text { Event }\end{array}$ & Frequency & $\begin{array}{c}\text { Cum. } \\
\text { Freq }\end{array}$ & $\begin{array}{c}\% \\
\text { Freq }\end{array}$ & $\begin{array}{c}\% \\
\text { Cum. } \\
\text { Freq }\end{array}$ & $\begin{array}{c}\text { Random } \\
\text { Numbers }\end{array}$ \\
\hline No Penalty & 22 & 22 & $63 \%$ & $63 \%$ & $01-63$ \\
Penalty $2.5 \%$ & 2 & 24 & $6 \%$ & $69 \%$ & $64-69$ \\
Penalty $5 \%$ & 11 & 35 & $31 \%$ & $100 \%$ & $70-100$ \\
\hline
\end{tabular}

We do over the prior step each raw material for all suppliers. The key result from example illustration in Table $\mathbf{2}$ is the value of random numbers that will determine supplier delivery performance. Random numbers between 0 to 100 range are generated using spreadsheet for four periods. The result of generated random numbers will be matched to the random numbers in accordance with each supplier late delivery rate distribution. Table 3 shows the result of Monte Carlo simulation delivery rate all suppliers for four periods. It will be an input in the mathematical formulation for parameter $L_{i s t}$. 
Table 3 Late delivery penalty monte carlo simulation

\begin{tabular}{|c|c|c|c|c|c|c|c|c|c|c|c|c|c|c|c|c|}
\hline \multirow{2}{*}{$\begin{array}{l}\text { Period } \\
\text { Supplier }\end{array}$} & \multicolumn{8}{|c|}{1} & \multicolumn{8}{|c|}{2} \\
\hline & $D$ & $E$ & $\mathrm{~F}$ & G & $\mathrm{H}$ & $M$ & $\mathrm{~N}$ & 0 & D & $E$ & $\mathrm{~F}$ & G & $\mathrm{H}$ & $M$ & $\mathrm{~N}$ & 0 \\
\hline Random Numbers & 73 & 91 & 25 & 17 & 75 & 30 & 65 & 85 & 31 & 36 & 20 & 58 & 87 & 16 & 2 & 21 \\
\hline Penalty & $2,5 \%$ & $5 \%$ & $0 \%$ & $0 \%$ & $2,5 \%$ & $0 \%$ & $3 \%$ & $5 \%$ & $0 \%$ & $0 \%$ & $0 \%$ & $3 \%$ & $5 \%$ & $0 \%$ & $0 \%$ & $0 \%$ \\
\hline Period & \multicolumn{8}{|c|}{3} & \multicolumn{8}{|c|}{4} \\
\hline Supplier & $D$ & $E$ & $\mathrm{~F}$ & $G$ & $\mathrm{H}$ & $M$ & $\mathrm{~N}$ & 0 & $D$ & $E$ & $\mathrm{~F}$ & $G$ & $\mathrm{H}$ & $M$ & $\mathrm{~N}$ & 0 \\
\hline Random Numbers & 41 & 53 & 82 & 82 & 82 & 79 & 96 & 82 & 70 & 78 & 60 & 44 & 23 & 13 & 23 & 69 \\
\hline Penalty & $0 \%$ & $0 \%$ & $5 \%$ & $3 \%$ & $5 \%$ & $3 \%$ & $5 \%$ & $3 \%$ & $2,5 \%$ & $5 \%$ & $3 \%$ & $0 \%$ & $0 \%$ & $0 \%$ & $0 \%$ & $3 \%$ \\
\hline
\end{tabular}

Another uncertainty factor as mentioned earlier is product/raw material quality rate. The company owns raw material quality standard as shown as Table 4. A raw material has two chemical parameters that must be met. If the suppliers deliver raw materials that do not meet the quality standard, they will be charged. The amount of penalty charge is measured from the quality range of product delivered by the supplier to the quality standard.

Table 4 Raw material quality standard

\begin{tabular}{lll}
\hline \multicolumn{1}{c}{ Raw Material } & \multicolumn{1}{c}{ Parameter } & \multicolumn{1}{c}{ Standard } \\
\hline \multirow{2}{*}{ Iron sand } & $\mathrm{Fe}_{2} \mathrm{O}_{3}$ & $\mathrm{Min} 50 \%$ \\
& $\mathrm{H}_{2} \mathrm{O}$ & $\mathrm{Max} 5 \%$ \\
\hline \multirow{2}{*}{ Trass } & $\mathrm{SiO}_{2}+\mathrm{R}_{2} \mathrm{O}_{3}$ & $\mathrm{Min} 75 \%$ \\
& $\mathrm{H}_{2} \mathrm{O}$ & $\mathrm{Max} 10 \%$ \\
\hline \multirow{2}{*}{ Silica sand } & $\mathrm{SiO}_{2}$ & $\mathrm{Min} 90 \%$ \\
& $\mathrm{H}_{2} \mathrm{O}$ & $\mathrm{Max} 6 \%$ \\
\hline
\end{tabular}

Historical data of raw material quality rate is collected from all suppliers. We analyze the data using statistics descriptive in a spreadsheet. The output is used to calculate the number of class interval $(\mathrm{k})$ and the size of class interval (p) in Sturges Rules formula. According to Brkic (1991) the formula is

$$
\begin{gathered}
k=1+3,3 \log n \\
p=\frac{R}{k}
\end{gathered}
$$

Where $n$ express the total number of observations the dataset and $\mathrm{R}$ is the data ranges.

The result of calculation will be used to set the lower bound and the upper bound in making the frequency distributions and cumulative frequency/probability distributions. The frequency distributions value is obtained from how often those value emerge in between the lower bound and the upper bound data observation ranges. Then, we put the interval of random numbers on every class interval. For example, Table 5 shows the result of iron sand quality distribution for parameter $\mathrm{Fe} 2 \mathrm{O} 3$ delivered by supplier D.

Table 5 Iron sand quality distribution for parameter $\mathrm{Fe}_{2} \mathrm{O}_{3}$

\begin{tabular}{cccccccc}
\hline Lower Bound & Upper Bound & Median & Frequency & Cum. Freq & \% Freq & \% Cum. Freq & Random Numbers \\
\hline 33,89 & 39,61 & 36,75 & 3 & 3 & $2 \%$ & $2 \%$ & $01-02$ \\
39,62 & 45,34 & 42,48 & 3 & 6 & $2 \%$ & $4 \%$ & $03-04$ \\
45,35 & 51,07 & 48,21 & 6 & 12 & $4 \%$ & $9 \%$ & $05-08$ \\
51,08 & 56,80 & 53,94 & 8 & 20 & $6 \%$ & $14 \%$ & $09-13$ \\
56,81 & 62,53 & 59,67 & 73 & 93 & $52 \%$ & $66 \%$ & $14-65$ \\
62,54 & 68,26 & 65,40 & 32 & 125 & $23 \%$ & $89 \%$ & $66-88$ \\
68,27 & 73,99 & 71,13 & 8 & 133 & $6 \%$ & $95 \%$ & $89-94$ \\
74,00 & 80,12 & 77,06 & 7 & 140 & $5 \%$ & $100 \%$ & $95-100$ \\
\hline
\end{tabular}

Table 6 Low quality penalty monte carlo simulation

\begin{tabular}{l|cccc|cccc}
\hline Supplier & \multicolumn{3}{c}{ D } & \multicolumn{3}{c}{ E } \\
\hline Period & $\mathbf{1}$ & $\mathbf{2}$ & $\mathbf{3}$ & $\mathbf{4}$ & $\mathbf{1}$ & $\mathbf{2}$ & $\mathbf{3}$ \\
\hline Random Numbers $\left(\mathrm{Fe}_{2} \mathrm{O}_{3}\right)$ & 62 & 93 & 51 & 90 & 73 & 72 & 51 & 13 \\
Quality Rate Simulation $\left(\mathrm{Fe}_{2} \mathrm{O}_{3}\right)$ & $59,67 \%$ & $71,13 \%$ & $59,67 \%$ & $71,13 \%$ & $59,25 \%$ & $59,25 \%$ & $59,25 \%$ & $48,89 \%$ \\
\hline Random Numbers $\left(\mathrm{H}_{2} \mathrm{O}\right)$ & 60 & 7 & 15 & 65 & 14 & 16 & 38 & 31 \\
Quality Rate Simulation $\left(\mathrm{H}_{2} \mathrm{O}\right)$ & $5,66 \%$ & $3,20 \%$ & $4,02 \%$ & $5,66 \%$ & $3,89 \%$ & $4,41 \%$ & $4,93 \%$ & $4,41 \%$ \\
\hline Penalty $\left(\mathrm{Fe}_{2} \mathrm{O}_{3}\right)$ & - & - & - & - & - & - & - & $1,11 \%$ \\
\hline Penalty $\left(\mathrm{H}_{2} \mathrm{O}\right)$ & $0,66 \%$ & - & - & $0,66 \%$ & - & - & - & - \\
\hline Low Quality Rate $\left(\mathrm{Fe} 2 \mathrm{O} 3+\mathrm{H}_{2} \mathrm{O}\right)$ & $0,66 \%$ & $0,00 \%$ & $0,00 \%$ & $0,66 \%$ & $0,00 \%$ & $0,00 \%$ & $0,00 \%$ & $1,11 \%$ \\
\hline
\end{tabular}

We repeat the previous step each raw material in every parameter quality for all suppliers. The key point from Table 5 is the value of random numbers in every class interval. Random numbers between 0 to 100 range are generated using spreadsheet for four periods. The result of generated random numbers will be matched to the random numbers under each supplier's raw material quality distributions. Table 6 shows the result of the example Monte Carlo simulation in low quality rate for supplier D and supplier E.
This result as an input in the mathematical formulation for parameter $Q_{\text {ist }}$.

As a multiple dedicated suppliers problem, we discuss the minimum percentage for order to the suppliers with the company management. This is to fulfill the data of management policy constraint (nist). The constraint is a distinctive constraint. It makes the order must be divided to all suppliers because of the suppliers have a high bargaining power to the company. So, the company decide to keep ordering yet as minimum as possible. We also ask to the 
suppliers to determine the minimum order, as stated as in supplier requirement constraint (constraint number 9), that they required. Table 7 shows raw material minimum order each supplier according to the buyer management policy and supplier requirements.

Table 7 Raw material minimum order

\begin{tabular}{cccc} 
Raw Material & Supplier & $\begin{array}{c}\text { Management } \\
\text { Policy (\% of } \\
\text { Demand) }\end{array}$ & $\begin{array}{c}\text { Supplier } \\
\text { Requirements } \\
\text { (Ton) }\end{array}$ \\
\hline Iron sand & D & $40 \%$ & 1500 \\
\hline Trass & E & $40 \%$ & 3000 \\
\hline Silica sand & F & $25 \%$ & 3000 \\
& H & $25 \%$ & 5000 \\
& N & $25 \%$ & 3500 \\
\hline & O & $30 \%$ & 3000 \\
& & $30 \%$ & 4000 \\
& & & 3500 \\
\hline
\end{tabular}

All completed data parameters are inputted into the model in the spreadsheet. We run the full model in Lingo 11.0.0.20 to satisfy raw materials demand shown in Table 8. The total demand for iron sand is 25700 ton, trass is 105.470 ton, and silica sand is 107810 ton. The demands are for four periods. The specification computer that we used is AMD Ryzen 7 2700U CPU Processor and 8 GB RAM.
Table 8 Raw materials demand (ton)

\begin{tabular}{lrrrc}
\hline \multirow{2}{*}{ Raw Material } & \multicolumn{4}{c}{ Period } \\
\cline { 2 - 5 } & $\mathbf{1}$ & $\mathbf{2}$ & $\mathbf{3}$ & $\mathbf{4}$ \\
\hline Iron sand & 5.900 & 3.500 & 8.150 & 8.150 \\
Trass & 19.970 & 23.250 & 30.000 & 32.250 \\
Silica sand & 26.110 & 15.470 & 36.110 & 30.120 \\
\hline
\end{tabular}

The result of software optimization shows a global optimum solution has been found. The value of objective function on this case is IDR 57,8 billion. Z1 (purchasing cost) is IDR 29,1 billion, Z2 (order cost) is IDR 3,8 billion, $\mathrm{Z} 3$ (inventory holding cost) is IDR 0,15 billion, Z4 (carrier cost) is IDR 23,9 billion, Z5 (late delivery penalty cost) is IDR 0,52 billion, and Z6 (low-quality penalty cost) is IDR 0,27 billion. All developed constraints are fully satisfied. All multiple dedicated suppliers supply the raw materials.

The total amount of order for iron sand is 22900 ton, trass 106408 ton, and silica sand is 108894 ton. It is for four periods. As we know, the total amount of iron sand is lower than the demand as mentioned earlier. This is because the inventory level of iron sand in initial period (IAit) is greater than zero, which is 4.818 ton. Otherwise, since trass and silica have no initial inventory level (IAit), the total amount of order for trass and silica sand are lesser than the demand. Table 9 and Table 10 show the details of the decision variables, which the result from the optimization.

Table 9 Optimization result of decision variables $\left(X_{i s c t}\right.$ and $\left.N_{i s c t}\right)$

\begin{tabular}{|c|c|c|c|c|c|c|c|c|c|c|}
\hline \multirow{3}{*}{ Raw Material } & \multirow{3}{*}{ Supplier } & \multirow{3}{*}{ Carrier } & \multicolumn{4}{|c|}{$X_{\text {isct }}$} & \multicolumn{4}{|c|}{$N_{\text {isct }}$} \\
\hline & & & \multicolumn{4}{|c|}{ Period } & \multicolumn{4}{|c|}{ Period } \\
\hline & & & 1 & 2 & 3 & 4 & 1 & 2 & 3 & 4 \\
\hline \multirow[t]{4}{*}{ Iron sand } & $D$ & C1 & 20 & 0 & 20 & 20 & 1 & 0 & 1 & 1 \\
\hline & & $\mathrm{C} 2$ & 2.340 & 1.500 & 3.240 & 3.240 & 78 & 50 & 108 & 108 \\
\hline & $E$ & $\mathrm{C} 1$ & 0 & 0 & 20 & 20 & 0 & 0 & 1 & 1 \\
\hline & & $\mathrm{C} 2$ & 3.000 & 3.000 & 3.240 & 3.240 & 100 & 100 & 108 & 108 \\
\hline \multirow[t]{8}{*}{ Trass } & $\mathrm{F}$ & C3 & 5.000 & 19.912 & 7.504 & 8.064 & 625 & 2489 & 938 & 1.008 \\
\hline & & $\mathrm{C} 5$ & 0 & 0 & 0 & 0 & 0 & 0 & 0 & 0 \\
\hline & $G$ & C3 & 0 & 0 & 0 & 0 & 0 & 0 & 0 & 0 \\
\hline & & C4 & 10.096 & 5.816 & 7.512 & 8.064 & 1.262 & 727 & 939 & 1.008 \\
\hline & & C5 & 0 & 0 & 0 & 0 & 0 & 0 & 0 & 0 \\
\hline & $\mathrm{H}$ & C3 & 0 & 0 & 0 & 0 & 0 & 0 & 0 & 0 \\
\hline & & C4 & 5.000 & 5.816 & 7.504 & 16.120 & 625 & 727 & 938 & 2.015 \\
\hline & & C5 & 0 & 0 & 0 & 0 & 0 & 0 & 0 & 0 \\
\hline \multirow{8}{*}{ Silica sand } & & $\mathrm{C} 4$ & 11.024 & 4.648 & 10.840 & 9.048 & 1.378 & 581 & 1.355 & 1.131 \\
\hline & & $\mathrm{C} 5$ & 0 & 0 & 0 & 0 & 0 & 0 & 0 & 0 \\
\hline & $\mathrm{N}$ & C3 & 0 & 0 & 0 & 0 & 0 & 0 & 0 & 0 \\
\hline & & C4 & 7.840 & 10.256 & 10.840 & 9.040 & 980 & 1.282 & 1.355 & 1.130 \\
\hline & & $\mathrm{C} 5$ & 0 & 0 & 0 & 0 & 0 & 0 & 0 & 0 \\
\hline & 0 & C3 & 0 & 0 & 0 & 0 & 0 & 0 & 0 & 0 \\
\hline & & C4 & 7.838 & 4.648 & 10.840 & 12.032 & 980 & 581 & 1.355 & 1.504 \\
\hline & & $\mathrm{C} 5$ & 0 & 0 & 0 & 0 & 0 & 0 & 0 & 0 \\
\hline
\end{tabular}

In Table 9, the optimization result of the decision variables is provided. The amount of raw material $\mathrm{i}$ order supplied by supplier s using carrier $\mathrm{c}$ in period $\mathrm{t}$ is notated by Xisct. In total, supplier D supplies 10.380 ton and supplier E supplies 12.250 ton of iron sand. To fulfill the demand of trass, the buyer order from supplier F of 40480 tons, supplier $\mathrm{G}$ of 31.488 ton, and supplier H of 34.440 ton. The silica sand order is divided to supplier $\mathrm{M}$ of 35560 tons, supplier $\mathrm{N}$ of 37.976 ton and supplier of $\mathrm{O}$ of 35.358 ton. In the next column of Xisct in Table 9, there is also provided Nisct. This decision variable shows the number of carriers needed. Supplier D needs 3 units of 20 ton truck capacity $(\mathrm{C} 1)$ and 344 units of 30 ton truck capacity (C2) to supply iron sand in total. Supplier E, as also an iron sand supplier, requires 2 
units of $\mathrm{C} 1$ and 416 units of $\mathrm{C} 2$ for four periods. Supplier F merely needs 5.060 units of 8 ton truck capacity (C3) to deliver all trass order. Supplier G and supplier H need less carrier than supplier F to fulfill the order. Supplier G needs 3.936 units of 8 ton truck capacity (C4) and supplier $\mathrm{H}$ requires 4.305 units. All suppliers of silica sand need $\mathrm{C} 4$, which is the truck with 8 ton capacity, to carry all their orders. Supplier M requires 4.445 units, supplier N needs 4.747 units, and supplier O should prepare 4.420 units to deliver the order. Details of Xisct and Nisct in every period can be traced in Table 9. The developed model also optimizes the inventory level of raw material $\mathrm{i}$ in period $\mathrm{t}$. It is notated by INVit. This decision variable aims to determine the amount of inventory that must be stored to meet the demands. Table 10 shows the optimization result of INVit decision variable.

Table 10 Optimization result of decision variable $\left(I N V_{i t}\right)$

\begin{tabular}{ccccc}
\hline \multirow{2}{*}{ Raw Material } & \multicolumn{4}{c}{ Period } \\
\cline { 2 - 5 } & $\mathbf{1}$ & $\mathbf{2}$ & $\mathbf{3}$ & $\mathbf{4}$ \\
\hline Iron sand & 4.069 & 5.278 & 3.648 & 1.774 \\
Trass & 1,2 & 7.984 & 2 & 737 \\
Silica sand & 4,1 & 4.674 & 0 & 784 \\
\hline
\end{tabular}

The optimum inventory level in the last period for iron sand is 1774 ton, trass is 737 ton, and silica sand is 784 ton. Inventory level can not to be summed over periods, so we count the average of inventory level. This is because the inventory level in period $t$ affects the number of orders for period $t+1$. The result of inventory level average is 3.962 ton for iron sand, 2.181 ton for trass, and 1.365 ton for silica sand.

\section{CONCLUSION}

In today's business competition, a proper supply chain management practice offers the opportunity to reduce costs and improves the company's competitiveness. As a part of practices, supplier selection and order allocation process have important roles. A structured and comprehensive method may be needed to optimize the value. A conceptual model that provided in this paper attempts to build the order allocation in multi products, multi suppliers, multi carriers, and multi periods problem under uncertainty more structured and comprehensive. This study also develops a mathematical formulation properly in MILP model to optimize the supply chain costs as an objective function. Monte Carlo simulation applies to the model to overcome the uncertainty issue in supplier delivery performance and product quality. The proposed model that experimented in real-world case successfully provided a global optimum solution. The research contributes to provide a powerful guide for company decision makers in determining supplier selection and order allocation. Future research should add more relevant variables to provide a solution for more complex problems. A sensitivity analysis is necessary to be considered to find out the impact of changes in uncertainty variables on the result of the models. Furthermore, because of software capability, more complex problems will consume much time. A heuristic method should be proposed to overcome this issue.

\section{REFERENCES}

Aissaoui, N., Haouari, M., \& Hassini, E. (2007). Supplier selection and order lot sizing modeling: A review. Computers \& Operations Research, 34(12), 3516-3540. DOI: 10.1016/j.cor.2006.01.016

Brkić, D. (1991). A method for evaluation of number class intervals of histogram. Microelectronics Reliability, 31(2-3), 245-248. DOI: 10.1016/0026-2714(91)90206-m

Costantino, N., \& Pellegrino, R. (2010). Choosing between single and multiple sourcing based on supplier default risk: A real options approach. Journal of Purchasing and Supply Management, $\quad 16(1), \quad 27-40 . \quad$ DOI: 10.1016/j.pursup.2009.08.001

Chen, C., Lin, C., \& Huang, S. (2006). A fuzzy approach for supplier evaluation and selection in supply chain management. International Journal of Production $\begin{array}{lrr}\text { Economics, } & 102(2), & 289-301 .\end{array}$ 10.1016/j.ijpe.2005.03.009

Choudhary, D., \& Shankar, R. (2013). Joint decision of procurement lot-size, supplier selection, and carrier selection. Journal of Purchasing and Supply Management, 19(1), 1626. DOI: $10.1016 /$ j.pursup.2012.08.002

Ekinci, Esra., \& Ornek, Arslan M. (2007). A Heuristic Approach for Determining Lot Sized and Schedules Using Power-ofTwo Policy. Journal of Applied Mathematics \& Decision Sciences. DOI: $10.1155 / 2007 / 53606$

Gentle, J. (2010). Computational Statistics. International Encyclopedia of Education, 93-97. DOI: 10.1016/b978-0-08044894-7.01316-6

Ghodsypour, S., \& O'Brien, C. (2001). The total cost of logistics in supplier selection, under conditions of multiple sourcing, multiple criteria, and capacity constraint. International Journal of Production Economics, 73(1), 15-27. DOI: 10.1016/s0925-5273(01)00093-7

Hamdan, S., \& Cheaitou, A. (2017). Supplier selection and order allocation with green criteria: An MCDM and multi-objective optimization approach. Computers \& Operations Research, 81, 282-304. DOI: 10.1016/j.cor.2016.11.005

Hosseini, A., Soltani, S., \& Mehdizadeh, M. (2018). Competitive Advantage and Its Impact on New Product Development Strategy (Case Study: Toos Nirro Technical Firm). Journal of Open Innovation: Technology, Market, And Complexity, 4(2), 17. DOI: $10.3390 /$ joitmc4020017

Jolai, F., Yazdian, S., Shahanaghi, K., \& Azari Khojasteh, M. (2011). Integrating fuzzy TOPSIS and multi-period goal programming for purchasing multiple products from multiple suppliers. Journal of Purchasing and Supply Management, 17(1), 42-53. DOI: 10.1016/j.pursup.2010.06.004

Kaur, H., \& Singh, S. (2017). Flexible dynamic sustainable procurement model. Annals of Operations Research, 273(12), 651-691. DOI: 10.1007/s10479-017-2434-2

Kumar, G., Rao, M., \& Rao, V. (2018). Supplier Selection and Order Allocation in Supply Chain. Materials Today: $\begin{array}{lll}\text { Proceedings, 5(5), 12161-12173. } & \text { DOI: }\end{array}$ 10.1016/j.matpr.2018.02.194

Mazdeh, M., Emadikhiav, M., \& Parsa, I. (2015). A heuristic to solve the dynamic lot sizing problem with supplier selection and quantity discounts. Computers \& Industrial Engineering, 85, 33-43. DOI: 10.1016/j.cie.2015.02.027

Mendoza, A., \& Ventura, J. (2010). A serial inventory system with supplier selection and order quantity allocation. European Journal of Operational Research, 207(3), 1304-1315. DOI: 10.1016/j.ejor.2010.06.034

Moheb-Alizadeh, H., \& Handfield, R. (2019). Sustainable supplier selection and order allocation: A novel multi-objective programming model with a hybrid solution approach. 
Computers \& Industrial Engineering, 129, 192-209. DOI: 10.1016/j.cie.2019.01.011

Mujkic, Z., \& Qorri, A., \& Kraslawski, A. (2018). Sustainability and Optimization of Supply Chains: a Literature Review. Operations and Supply Chain Management: An International Journal, 11(4),

186-199. http://doi.org/10.31387/oscm0350213

Pan, A. (1989). Allocation of Order Quantity Among Suppliers. Journal of Purchasing and Materials Management, 25(3), 36-39. DOI: 10.1111/j.1745-493x.1989.tb00489.x

Pan, W., \& Wang, F. (2014). A Multi-objective Model under Considering Disruption Risk and Scenario Analysis for Order Allocation in a Supply Chain Environment: An Integrated Multi-Objective Model for Order Allocation. Proceedings of the 2014 International Conference on Global Economy, Commerce and Service Science. DOI: 10.2991/gecss14.2014 .81

Romero-Hernandez, O., \& Romero-Hernandez, S., \& Shivaani, M. (2021). A Supply Chain Selection Method for Early-Stage Companies Based on an Adapted Quality Function Deployment Optimization Approach. Operations and Supply Chain Management: An International Journal, 14(2), 133147. http://doi.org/10.31387/oscm0450292

Stanford, J., \& Ziemke, J. (1994). Field (MAP) Statistics. Methods in Experimental Physics, 457-479. doi: 10.1016/s0076$695 x(08) 60266-5$
Tersine, Richard J. (1994). Principles of Inventory and Material Managements Fourth Edition. New Jersey: Prentice Hall International

Ustun, O., \& Demirtas, E. (2008). An integrated multi-objective decision-making process for multi-period lot-sizing with supplier selection 10.1016/j.omega.2006.12.004

Ware, N., Singh, S., \& Banwet, D. (2014). A mixed-integer nonlinear program to model dynamic supplier selection problem. Expert Systems with Applications, 41(2), 671-678. DOI: 10.1016/j.eswa.2013.07.092

Wicaksono, P., Pujawan, I., \& Widodo, E. (2019). A mixed integer linear programming model for dynamic supplier and carrier selection problems. International Journal of Procurement Management, 12(3), 276. DOI: 10.1504/ijpm.2019.099550

Wicaksono, P., Pujawan, I., Widodo, E., Sutrisno, \& Izzatunnisa, L. (2018). Mixed integer linear programming model for dynamic supplier selection problem considering discounts. MATEC Web of Conferences, 154, 01071. DOI: $10.1051 /$ matecconf $/ 201815401071$ doi.org/10.1051/matecconf/201815401071

Xia, W., \& Wu, Z. (2007). Supplier selection with multiple criteria in volume discount environments. Omega, 35(5), 494-504. DOI: 10.1016/j.omega.2005.09.00

\section{APPENDIX 1: COSTS (IDR), STORAGE CAPACITY (TON) AND INITIAL INVENTORY LEVEL (TON)}

\begin{tabular}{cccccccc}
\hline \multirow{2}{*}{ Raw Material } & Unit Cost & Order Cost & Late Del Penalty Cost & Low Qual Penalty Cost & Holding Cost & Storage Capacity & Initial Inv \\
\cline { 2 - 8 } & IDR & IDR & IDR & IDR & $\%$ & Ton & Ton \\
\hline Iron sand & 425.000 & 118.520 .800 & 425.000 & 425.000 & $2 \%$ & 15000 & 4818 \\
Trass & 85.000 & 119.270 .800 & 85.000 & 85.000 & $2 \%$ & 40000 & 0 \\
Silica sand & 95.000 & 119.770 .800 & 95.000 & 95.000 & $2 \%$ & 45000 & 0 \\
\hline
\end{tabular}

\section{APPENDIX 2: CARRIER COSTS (IDR)}

\begin{tabular}{ccc|cc|ccc|ccc}
\hline \multirow{2}{*}{ Raw Material } & \multicolumn{2}{c|}{ Supplier D } & \multicolumn{2}{c|}{ Supplier E } & \multicolumn{3}{c|}{ Supplier F } & \multicolumn{3}{c}{ Supplier G, H, M, N, and O } \\
\cline { 2 - 11 } & C1 & C2 & C1 & C2 & C3 & C4 & C5 & C3 & C4 & C5 \\
\hline Iron sand & 10.500 .000 & 12.000 .000 & 10.500 .000 & 12.000 .000 & & & & & & \\
Trass & & & & & 548.000 & 1.800 .000 & 3500000 & 432.000 & 548.000 & 1.800 .000 \\
Silica sand & & & & & & & & 432.000 & 548.000 & 1.800 .000 \\
\hline
\end{tabular}

APPENDIX 3: CARRIER CAPACITY (TON)

\begin{tabular}{|c|c|c|c|c|c|c|c|c|c|c|}
\hline \multirow{2}{*}{ Raw Material } & \multicolumn{2}{|c|}{ Supplier D } & \multicolumn{2}{|c|}{ Supplier E } & \multicolumn{3}{|c|}{ Supplier F } & \multicolumn{3}{|c|}{ Supplier $\mathrm{G}, \mathrm{H}, \mathrm{M}, \mathrm{N}$, and $\mathrm{O}$} \\
\hline & C1 & C2 & C1 & C2 & C3 & C4 & C5 & C3 & C4 & C5 \\
\hline Iron sand & 20 & 30 & 20 & 30 & & & & & & \\
\hline Trass & & & & & 8 & 15 & 30 & 5 & 8 & 15 \\
\hline Silica sand & & & & & & & & 5 & 8 & 15 \\
\hline
\end{tabular}


APPENDIX 4: SUPPLIER CAPACITY AND MINIMUM ORDER (TON)

\begin{tabular}{rccc}
\hline \multirow{2}{*}{ Raw Material } & Supplier & Supplier Capacity & Minimum Order \\
\cline { 3 - 4 } & & Ton & Ton \\
\hline Iron sand & D & 9000 & 1500 \\
& E & 9500 & 3000 \\
Trass & F & 35000 & 3000 \\
& G & 33000 & 5000 \\
& H & 34000 & 3500 \\
\hline
\end{tabular}

\begin{tabular}{llcc}
\hline \multirow{2}{*}{ Raw Material } & Supplier & $\begin{array}{c}\text { Supplier } \\
\text { Capacity }\end{array}$ & $\begin{array}{c}\text { Minimum } \\
\text { Order }\end{array}$ \\
\cline { 3 - 4 } & & Ton & Ton \\
\hline Silica sand & M & 40000 & 3000 \\
& N & 38000 & 4000 \\
& O & 39000 & 3500
\end{tabular}

\section{APPENDIX 5: MONTE CARLO SIMULATION}

\begin{tabular}{rccccccccc}
\hline & \multicolumn{1}{c}{ Late Delivery } & \multicolumn{4}{c}{ Low Quality } \\
\hline Raw Material & Supplier & $\mathbf{1}$ & $\mathbf{2}$ & $\mathbf{3}$ & $\mathbf{4}$ & $\mathbf{1}$ & $\mathbf{2}$ & $\mathbf{3}$ & $\mathbf{4}$ \\
\hline Iron sand & $\mathrm{D}$ & $2,50 \%$ & $0,00 \%$ & $0,00 \%$ & $2,50 \%$ & $0,66 \%$ & $0,00 \%$ & $0,00 \%$ & $0,66 \%$ \\
& $\mathrm{E}$ & $5,00 \%$ & $0,00 \%$ & $0,00 \%$ & $5,00 \%$ & $0,00 \%$ & $0,00 \%$ & $0,00 \%$ & $1,11 \%$ \\
Trass & $\mathrm{F}$ & $0,00 \%$ & $0,00 \%$ & $5,00 \%$ & $2,50 \%$ & $2,08 \%$ & $1,00 \%$ & $0,00 \%$ & $2,37 \%$ \\
& $\mathrm{G}$ & $0,00 \%$ & $2,50 \%$ & $2,50 \%$ & $0,00 \%$ & $0,00 \%$ & $0,10 \%$ & $0,10 \%$ & $1,65 \%$ \\
& $\mathrm{H}$ & $2,50 \%$ & $5,00 \%$ & $5,00 \%$ & $0,00 \%$ & $1,20 \%$ & $0,00 \%$ & $0,00 \%$ & $0,00 \%$ \\
Silica sand & $\mathrm{M}$ & $0,00 \%$ & $0,00 \%$ & $2,50 \%$ & $0,00 \%$ & $0,01 \%$ & $1,35 \%$ & $0,01 \%$ & $3,17 \%$ \\
& $\mathrm{~N}$ & $2,50 \%$ & $0,00 \%$ & $5,00 \%$ & $0,00 \%$ & $1,35 \%$ & $0,27 \%$ & $3,18 \%$ & $3,18 \%$ \\
& $\mathrm{O}$ & $5,00 \%$ & $0,00 \%$ & $2,50 \%$ & $2,50 \%$ & $3,25 \%$ & $1,08 \%$ & $4,25 \%$ & $0,28 \%$ \\
\hline
\end{tabular}

APPENDIX 6: OBJECTIVE FUNCTION (IN MILLION IDR)

\begin{tabular}{ccccccc} 
Z1 & Z2 & Z3 & Z4 & Z5 & Z6 & Total \\
\hline 29.122 & 3.817 & 151 & 23.291 & 525 & 273 & 57.808
\end{tabular}

Ary Tri Wibowo is a certified supply chain professional who experienced in Fast-Moving Consumer Good (FMCG) and manufacturing industry. He obtained his undergraduate industrial engineering degree in Institut Teknologi Sepuluh Nopember, Surabaya, Indonesia. In 2018, he continued his master's degree in Industrial and Systems Engineering which aligned to his prior study. His interest research topic is in supply chain management, strategic and performance management, and operation management.

Niniet Indah Arvitrida is a lecturer in Department of Industrial and Systems Engineering, Institut Teknologi Sepuluh Nopember, Surabaya, Indonesia. She holds a PhD in Operational Research from Loughborough University, UK. She also has a Master of Engineering in Supply Chain Management and Bachelor of Engineering in Industrial Engineering, both obtained with honors (cum laude) in ITS, Indonesia. Niniet is an expert in developing quantitative modelling approaches, primarily in logistics and supply chain management context. Her research interests are supply chain management and operational research, particularly in simulation modelling (agent-based modelling, system dynamics, and discrete-event simulation).

Erwin Widodo was granted his master's degree from Ritsumeikan University of Kyoto and his Doctoral Degree from Hiroshima University both in Japan, in 2006 and 2012 respectively. His expertise is of multi-player decision-making in industry especially by using game theory. In this current period of 2020-2024, he is assigned as head of manufacturing, transportation and logistics research center in his institution, namely Institut Teknologi Sepuluh Nopember (ITS), Surabaya, Indonesia. He actively joins several international associations related to his field, i.e. IDGS, Informs, IAEng, IEOM and the likes. Moreover, he also joins as a reviewer in several international journals such as EJOR, JIPE, IJISE, OSCM, IJTech, Cogent Engineering, etc. 